\title{
PELATIHAN E-GOVERNMENT BAGI APARAT PEMERINTAH DESA DI KECAMATAN CIAMPEL KABUPATEN KARAWANG
}

\author{
Aos Kuswandi1), Dewi Kurniasih ${ }^{2),}$ Nia Karniawati ${ }^{3)}$ \\ 1) Program Studi Magister Ilmu Pemerintahan Universitas Islam 45 \\ 2),3) Program Studi Ilmu Pemerintahan Universitas Komputer Indonesia \\ Email : aos kuswandi@yahoo.com ${ }^{11}$, dewi.kurniasih@email.unikom.ac.id²), \\ nia.karniawati@email.unikom.ac.id ${ }^{3)}$
}

\begin{abstract}
ABSTRAK
Ditetapkannya UU No. 6 Tahun 2014 tentang Desa menuntut semakin baiknya penyelenggaraan pemerintahan desa dalam bidang pelayanan; pembangunan dan pemberdayaan masyarakat. Oleh menjadi penting dilaksanakan pemerintahan elektronik atau e-government pada tingkat pemerintahan desa. Kemampuan Desa dan aparatnya dalam e-government belum merata pada setiap desa di Indonesia. Aparatur pemerintah desa di Kecamatan Ciampel Kabupaten Karawang merupakan obyek sasaran program pengabdian masyarakat melalui pelatihan e-government, dengan jumlah peserta sebanyak 28 orang dari 7 Pemerintahan Desa. Hasil analisis menunjukan bahwa pemerintah desa sudah mulai menerapkan e-government dengan membuat web sederhana dan blog yang berisi informasi pemerintahan dan pembangunan desa.Untuk menjamin keberlanjutan program perlu dilakukan pembimbingan dan pendampingan dengan melibatkan Perguruan Tinggi, Pemerintah Daerah dan Desa.
\end{abstract}

Kata kunci: Pelatihan; E- Government; Aparat Pemerintah Desa; Pemerintah Desa.

\section{PENDAHULUAN}

Pasca reformasi politik dan pemerintahan Indonesia tahun 1997, sudah banyak perubahan dalam penyelenggaraan pemerintahan pada pemerintahan nasional maupun pemerintahan daerah. Pemerintahan berbasis kinerja menjadi tuntutan. Untuk itu transfaransi dan akuntabilitas penyelenggaraan pemerintahan harus diwujudkan. Sebagai upaya peningkatan kualitas penyelenggaraan pemerintahan daerah, semakin diperkuat dengan dikeluarkannya UU No. 23 Tahun 2014 tentang Pemerintahan Daerah dan UU No. 6 Tahun 2014 tentang Desa. Dua paket UU ini merupakan wujud komitmen pemerintah bahwa fokus dalam pelayanan dan pembangunan terletak di daerah dan desa.

Optimalisasi penyelenggaraan pembangunan dan pelayanan kepada masyarakat di tingkat desa penting untuk diwujudkan. Keberadaan sistem informasi dan internet menjadi penting dalam upaya mewujudkan kualitas penyelenggaraan pemerintahan di setiap lapisan. Pada tingkat pemerintahan desa juga menjadi penting dilaksanakan pemerintahan elektronik atau e-government. Dimanapun desa tersebut berada, dengan adanya pemerintahan elektronik atau $e$-government maka penyelenggaraan pelayanan kepada masyarakat dan komunikasi lintas pemerintahanpun bukan lagi kendala. Dengan adanya e- government maka dapat meningkatkan efisiensi internal, menyampaikan pelayanan publik, atau proses kepemerintahan yang demokratis, dan bisa berjalan lebih cepat. Dari berbagai literatur mengenai e government, bahwa keuntungan yang paling diharapkan dari e-government adalah peningkatan efisiensi, kenyamanan, serta aksesibilitas yang lebih baik dari pelayanan publik. Terkait dengan diskusi di atas, pada salah satu contoh seperti yang dilakukan oleh Hartoyo dkk (2016) dalam pelaksanaan program pendampingan masyarakat di Desa Citali Kabupaten Sumedang menyimpulkan hasil kegiatan menunjukkan bahwa secara umum warga telah merintis upaya pengelolaan dan pengembangan SID dengan menggunakan $e$ goverment sebagai salah satu amanat UU Desa.

\footnotetext{
1 Dosen Tetap Program Studi Magister Ilmu Pemerintahan Universitas Islam 45

Dosen Tetap Program Studi Ilmu Pemerintahan Universitas Komputer Indonesia

${ }^{3}$ Dosen Tetap Program Studi Ilmu Pemerintahan Universitas Komputer Indonesia
} 
Sejak digulirkannya dana desa pada tahun 2015 maka percepatan pembangunan semakin merata pada desa-desa di Indonesia. Namun di sisi lain agar transparansi dan akuntabilitas dalam pengelolaan dana desa tersebut dituntut komitmen dan kemampuan pengelola agar semua anggaran dan program yang dilaksanakan dapat tercatat dan terinformasikan dengan baik kepada publik. Ini merupakan tuntutan yang harus dipenuhi oleh setiap desa yang mendapatkan alokasi dana desa.

Pemerintah Kabupaten Karawang memiliki wilayah yang cukup luas dengan jumlah kecamatan dan desa yang cukup banyak. Pada sisi lain wilayah kabupaten Karawang menjadi kawasan pengembangan industri di Provinsi Jawa Barat. Kondisi demikian menuntut pemerintah daerah untuk meningkatkan kualitas pelayanan. Dengan demikian e-government sangat diperlukan. Konsep e-government didefinisikan oleh Eddy Satriya (2009) yaitu: Sebagai upaya pemanfaatan dan pendayagunaan telematika untuk meningkatkan efisiensi dan costeffective pemerintahan, memberikan berbagai jasa pelayanan kepada masyarakat secara lebih baik, menyediakan akses informasi kepada publik secara lebih luas, dan menjadikan penyelenggaraan pemerintahan lebih bertanggung jawab (accountable) serta transparan kepada masyarakat.Dalam konsep tersebut nampak bahwa e-government banyak manfaatnya bagi penyelenggaraan pemerintahan.

Terkait dengan manfaat yang lebih luas dengan adanya e-government dijelaskan oleh Richardus (2004:5) yaitu:

a. Memperbaiki kualitas pelayanan pemerintah kepada stakehodernya (masyarakat, kalangan bisnis dan industri) terutama dalam hal kinerja efektivitas dan efisiensi di berbagai bidang kehidupan bernegara.

b. Meningkatkan transparansi, kontrol, dan akuntabilitas penyelenggaraan pemerintahan dalam rangka pener apan konsep good corporate governance.

c. Mengurangi secara signifikan total biaya administrasi, relasi dan interaksi yang dikeluarkan pemerintah maupun stakeholdernya untuk keperluan aktivitas sehari-hari.

d. Memberikan peluang bagi pemerintah untuk mendapatkan sumber-sumber pendapatan baru melalui interaksinya dengan pihak-pihak yang berkepentingan.

e. Menciptakan suatu lingkungan masyarakat baru yang dapat secara tepat dan tepat menjawab berbagai permasalahan yang dihadapi sejalan dengan berbagai perubahan global dan trend yang ada.

f. Memperdayakan masyarakat dan pihak-pihak lain sebagai mitra pemerintah dalam proses pengambilan berbagai kebijakan publik secara merata dan demokratis

Berdasarkan uraian mengenai manfaat dari adanya e-government, sangat banyak. Intinya sangat bermanfaat bagi pemerintah, pengusana dan masyarakat. Oleh karenanya kegiatan pengabdian masyarakat dilakukan melelalui pelatihan e-government bagi aparat pemerintah desa

Salah satu wilayah kecamatan yang menjadi lokasi pengabdian kepada masyarakat yaitu Kecamatan Ciampel. Pada wilayah kecamatan ini kondisi masyarakat dan pemerintahan desanya memerlukan perhatian agar lebih optimal dalam penyelenggaraan pemerintahan. Minimnya kemampuan dan profesionalisme aparat pemerintah desa dalam bidang teknologi informasi memerlukan peningkatan untuk semakin lebih baik. Upaya pemberian pelatihan dan pendampingan kepada pemerintah desa dalam teknologi informasi e-government merupakan salah satu solusinya. Tulisan ini bertujuan untuk mendeskripsikan pelaksanaan pelatihan e-government bagi aparat pemerintah desa di Kecamatan Ciampel Kabupaten Karawang.

\section{METODE PELAKSANAAN PENGABDIAN}

Sasaran dan obyek kegiatan ini adalah para aparatur desa yang ada di wilayah Kecamatan Ciampel Kabupaten Karawang. Wilayah kecamatan Ciampel ini pada awalnya sebagai lokasi KKN Mahasiswa Program Studi Ilmu Pemerintahan Fakultas Ilmu Sosial dan Ilmu Politik Universitas Komputer Indonesia. Dengan demikian kegiatan Pengabdian kepada masyarakat ini merupakan tindaklanjut dari KKN tersebut. Secara administrasi pemerintahan, Kecamatan Ciampel memiliki 7 (tujuh desa). Terkait dengan data desa dan jumlah penduduk setiap desa di Kecamatan Ciampel dapat dilihat sebagai berikut: 
Tabel 1. Desa dan Jumlah Penduduk Se- Kecamatan Ciampel 2018

\begin{tabular}{|c|c|c|c|c|c|c|c|}
\hline \multirow[t]{2}{*}{ NO } & \multirow[t]{2}{*}{ DESA } & \multicolumn{3}{|c|}{ JUMLAH PENDUDUK } & \multicolumn{3}{|c|}{ JUMLAH KK } \\
\hline & & $\mathbf{L}$ & $\mathbf{P}$ & Jumlah & $\mathbf{L}$ & $\mathbf{P}$ & Jumlah \\
\hline 1 & Kutapohaci & 2.155 & 2.051 & 4.206 & 1.169 & 112 & 1.281 \\
\hline 2 & Kutanegara & 1.910 & 1.821 & 3.731 & 1.075 & 56 & 1.131 \\
\hline 3 & Kutamekar & 3.293 & 3.340 & 6.633 & 1.832 & 142 & 1.974 \\
\hline 4 & Mulyasari & 2.414 & 2.497 & 4.911 & 1.213 & 192 & 1.405 \\
\hline 5 & Mulyasejati & 3.339 & 3.250 & 6.589 & 1.648 & 259 & 1.907 \\
\hline 6 & Parungmulya & 2.709 & 2.513 & 5.222 & 2.138 & 89 & 2.227 \\
\hline 7 & Tegallega & 1.341 & 1.272 & 2.613 & 642 & 104 & 746 \\
\hline & JUMLAH & 17.161 & 16.744 & 16.744 & 9.717 & 945 & 10.671 \\
\hline
\end{tabular}

Sumber: kasi Kependudukan Kecamatan Ciampel, 2018

Selanjutnya aparat pemerintah desa yang dipilih dari setiap desa adalah mereka yang telah mengenal teknologi informasi dan penggunaan internet namun belum optimal dalam pelaksanan pada bidang tugasnya dalam pemerintahan desa. Peserta seluruhnya berjumlah 28 orang yang mewakili kelompok Kepala Desa, Sekretaris Desa dan para Kaur dalam Pemerintahan desa. Sebagai prioritas peserta adalah kepala urusan/ staf yang menangani urusan pelayanan umum bagi masyarakat. Dalam hal penetapan peserta terpilih pada program pelatihan e-government melibatkan pemerintah Kecamatan dalam hal ini Sekretaris Kecamatan. Hal ini dilakukan agar pelatihan yang diberikan menjadi tepat sasaran sehingga output maupun outcome dari pelatihan ini akan diperoleh sesuai dengan tujuan dari pengabdian kepada masyarakat.

Sesuai kebutuhan obyek sasaran, maka program yang diberikan adalah pelatihan $e$ government. Untuk itu maka terlebih dulu diidentifikasi kebutuhan dari sasaran. Setelah dilakukan identifikasi kebutuhan model pelatihan selanjutnya dirumuskan kurikulum dan capaian dari pelatihan yang akan diberikan. Untuk penyusunan kurikulum tersebut melibatkan 7 orang dalam satu tim yang masing-masing sebagai tutor dalam pelatihan. Adapun kurikulum dan capaian pembelajaran untuk setiap sesi adalah sebagai berikut:

Tabel 2. Kurikulum dan Capaian Pembelajaran/Pelatihan

\begin{tabular}{|c|c|c|}
\hline \\
\hline \multicolumn{3}{|c|}{$\begin{array}{l}\text { Nama Program : Pelatihan E- Government bagi Apatur Pemerintah Desa Se Kecamatan } \\
\text { Ciampel Kabupaten Karawang } \\
\text { Capaian Pelatihan: Peserta memiliki pengetahuan, wawasan mengenai konsep, kebijakan } \\
\text { dan aplikasi e government dalam penyelenggaraan pemerintahan desa serta mampu } \\
\text { menerapkannya dalam penyelenggaraan pemerintahan desa untuk mencapai kualitas } \\
\text { pelaksanaan pembangunan, pelayanan dan pemberdayaan masyarakat sebagai upaya } \\
\text { mewujudkan Tata Kelola Pemerintaha Desa Yang Baik (Good Governance). } \\
\text { No. Materi Pelatihan } \\
\text { Mapaian Pembelajaran/ Pelatihan }\end{array}$} \\
\hline \multicolumn{3}{|c|}{\begin{tabular}{l|l|l} 
No. & \multicolumn{1}{|c|}{ Materi Pelatihan } & \multicolumn{1}{c}{ Capaian Pembelajaran/ Pelatihan } \\
1. & Pemahaman Konsep $e^{-}$ & Peserta mengetahui, mengerti dan memahami konsep $e$ \\
& Government & government serta pentingnya dalam peningkatan kualitas \\
& pelaksanaan fungsi pemerintahan : pembangunan, pelayan \\
& dan pemberdayaan masyarakat dalam upaya mencapai Tata \\
& Kelola Pemerintahan Desa yang baik.
\end{tabular}} \\
\hline 2. & Kebijakan e-Government & $\begin{array}{l}\text { Peserta mengetahui, mengerti dan memahami berbagai } \\
\text { kebijakan e-government baik dari Pemerintah maupun } \\
\text { Pemerintah Daerah dan mampu menerapkannya dalam } \\
\text { pelaksanaan pemerintahan desa. }\end{array}$ \\
\hline 3. & $\begin{array}{l}\text { Teknik Presentasi (Power } \\
\text { Point) dan Public Speaking }\end{array}$ & $\begin{array}{l}\text { Peserta mengetahui, mengerti dan memahami serta mampu } \\
\text { membuat berbagai bahan presentasi terkait dengan } \\
\text { pelaksanaan fungsi pemerintahan sehingga dapat lebih } \\
\text { efektif dalam penyampaian pada berbagai forum. } \\
\text {-Selain itu peserta mengetahui, mengerti dan memahami } \\
\text { serta mampu membuat materi untuk disampaikan dalam } \\
\text { forum formal dengan penggunaan bahasa dan gaya dalam } \\
\text { bicara di depan umum. }\end{array}$ \\
\hline
\end{tabular}




\begin{tabular}{|l|ll|l|}
\hline & & & $\begin{array}{l}\text { Dengan dua kemampuan ini diharapkan pihak terkait } \\
\text { semakin percaya dan mau bekerjasama dan mendukung } \\
\text { program pemerintahan desa. }\end{array}$ \\
\hline 4. & $\begin{array}{l}\text { Pembuatan Aplikasi } e- \\
\text { Government }\end{array}$ & $\begin{array}{l}\text { Peserta mengetahui, mengerti dan memahami serta mampu } \\
\text { membuat berbagai media informasi sederhana berbasis } \\
\text { internet/web seperti blog, email dan optimalisasi } \\
\text { pemanfaatan media sosial sehingga dapat menggunakannya } \\
\text { untuk mendukung pelaksanaan fungsi pemerintahan dalam } \\
\text { mewujudkan Tata Kelola Pemerintahan Yang Baik. }\end{array}$ \\
\hline
\end{tabular}

Selanjutnya dari kurikulum pelatihan yang telah dibuat kemudian disusun jadwal teknis pelaksanaan pelatihan dengan susunan tutor yang dilaksanakan selama satu hari. Adapun Jadwal kegiatan secara rinci disususn sebagai berikut:

Tabel 3. Jadwal Kegiatan Pelatihan E-Government

\begin{tabular}{|c|c|c|}
\hline Waktu & Kegiatan & Pelaksana \\
\hline $07.00-08.00$ & Registrasi & Airinawati, A.Md \\
\hline $09.00-09.05$ & Pembukaan & Panitia \\
\hline $09.05-09.30$ & $\begin{array}{l}\text { Sambutan: } \\
\text { 1.Ketua Program Studi Ilmu } \\
\text { Pemerintahan FISIP Unikom sebagai } \\
\text { Ketua Pelaksana } \\
\text { 2.Ketua Program Studi Magister Ilmu } \\
\text { Pemerintahan Unisma '45’ Bekasi. } \\
\text { 3.Camat Kecamatan Ciampel } \\
\text { Kabupaten Karawang } \\
\text { 4.Dekan FISIP Unikom sekaligus } \\
\text { membuka acara }\end{array}$ & $\begin{array}{l}\text { Dr. Hj. Dewi Kurniasih, S.IP.,M.Si. } \\
\text { Dr. H. Aos Kuswandi, Drs.,M.Si. } \\
\text { Diwakili Sekcam: Irlan Suarlan, } \\
\text { S.TP.,M,Si. } \\
\text { Prof. Dr. H. Samugyo Ibnu Redjo, } \\
\text { Drs.,M.A. }\end{array}$ \\
\hline $09.30-09.40$ & Pembacaan Do'a & Indra Gunawan Wibiksana \\
\hline $09.40-10.00$ & Foto Bersama & Panitia \\
\hline $09.00-09.15$ & Coffee Break & Panitia \\
\hline $09.15-10.00$ & Pemahaman Konsep e-Government & Dr. H. Aos Kuswandi, Drs.,M.Si. \\
\hline $10.00-11.00$ & Kebijakan e-Government & $\begin{array}{l}\text { Nia Karniawati, S.IP.,M.Si. } \\
\text { Dr. Hj. Dewi Kurniasih, S.IP.,M.Si. }\end{array}$ \\
\hline $11.00-12.00$ & $\begin{array}{l}\text { Teknik Presentasi (Power Point) dan } \\
\text { Public Speaking }\end{array}$ & $\begin{array}{l}\text { Dr. Poni Sukaesih K, S.IP.,M.Si. } \\
\text { Tatik Rohmawati, S.IP.,M.Si. }\end{array}$ \\
\hline $12.00-13.00$ & Ishoma & Panitia \\
\hline $13.00-15.00$ & Pembuatan Aplikasi e-Government & Rino Adibowo, S.IP.,M.I.Pol. \\
\hline 15.00 & Penutup & Panitia \\
\hline
\end{tabular}

Kegiatan pelatihan ini dilaksanakan di Kampus UNIKOM di Jalan dipatiukur No. 102-118 Bandung, di ruang Laboratorium Komputer 11 Lantai 9 (R. 9028) pada hari Sabtu tanggal 20 Januari 2018.

Dalam pelaksanaannya peserta pelatihan datang ke kampus UNIKOM berombongan dengan swadana yang dikoordinir oleh Pemerintah Kecamatan Ciampel. Acara dibuka oleh Dekan FISIP Unikom yang sebelumnya diawali dengan beberapa sambutan dari Ketua Pelaksana, Ketua Program Magister Ilmu Pemerintahan Unisma Bekasi. Kegiatan pengabdian pada masyarakat ini diselenggarakan atas kerjasama Program Studi Ilmu Pemerintahan FISIP Unikom dan Program Magister Ilmu Pemerintahan Unisma Bekasi dan Pemerintah Kecamatan Ciampel Kabupaten Karawang.

Selama pelatihan berlangsung menggunakan perangkat computer dan jaringan internet yang ada di laboratorium computer 11 lantai 9 UNIKOM Bandung. Media penanyangan ilustrasi dan juga materi dalam hardcopy diberikan kepada peserta agar mereka lebih mudah dalam memahami materi pelatihan. Computer yang berada di laboriurm dipergunakan sepenuhnya oleh peserta 
dengan kemudahan akses internet. Dengan demikian pelaksanaan pelatihan e-government dapat berjalan dengan baik.

\section{HASIL DAN PEMBAHASAN}

Secara konseptual banyak definisi mengenai e-government. Salah satunya diuraikan secara sederhana oleh UNDP bahwa e-government adalah penggunaan teknologi informasi dan komunikasi (ICT- Information and Communicat-ion Technology) oleh pihak pemerintahan. Dalam hal ini bermakna bahwa pemerintah menggunakan ICT dalam pelaksanaan fungsi-fungsi pemerintahannya. E-government menurut Richardus (2004:9) adalah mekanisme dimana pemerintah menggunakan teknologi informasi (terutama internet) sebagai sarana utama yang menghubungkan antara dirinya dengan para stakeholder, yaitu masyarakat umum, kalangan industri, dan sektor publik lainnya. Terkait dengan definisi tersebut, Pemerintah telah mengeluarkan kebijakan yang berkaitan dengan e-government dalam Instruksi Presiden Republik Indonesia Nomor 3 Tahun 2003 Tentang Kebijakan Dan Strategi Nasional dinyatakan bahwa Pengembangan e-government merupakan upaya untuk mengembangkan penyelenggaraan kepemerintahan yang berbasis (menggunakan) elektronik dalam rangka meningkatkan kualitas layanan publik secara efektif dan efisien. Selain itu melalui e government dalam pelayanan maka masyarakat mendapatkan kenyamanan, serta aksesibilitas yang lebih baik dari pelayanan publik.

Desa sebagai ujung tombak dalam penyelenggaraan pemerintahan, memiliki tugas yang cukup berat, karena berhadapan langsung dengan masyarakat. Oleh karenanya desa perlu menerapkan metode yang lebih baik dalam memberikan pelayanan kepada masyarakat. E-government merupakan jawaban untuk mengatasi kelemahan pelayanan aparat pemerintah desa selama ini. Cara yang bisa ditempuh antara lain melalui membuat atau membangun sebuah halaman website sederhana atau blog untuk memberikan pelayanan administrasi dan interaksi kepada warga desa. Cara ini dipandang lebih efektif untuk melaksanakan pelayanan public. Melalui cara ini maka warga masyarakat yang membutuhkan pelayanan administratif, pelaporan atau membutuhkan informasi dapat menggunakan halaman web milik desa yang telah dibuat tersebut. Hal yang sama juga dapat dioptimalkan untuk mewujudkan transparansi penyusunan Anggaran Pendapatan dan Belanja Desa (APBDes). Dengan terbukanya informasi melalui internet masyarakt desa akan mengetahui sejak awal proses penganggaran dan perencanaan pembangunan di Desanya. Berkaitan dengan alur proses penyusunan APBDes misalnya, dapat dilihat dalam gambar berikut:

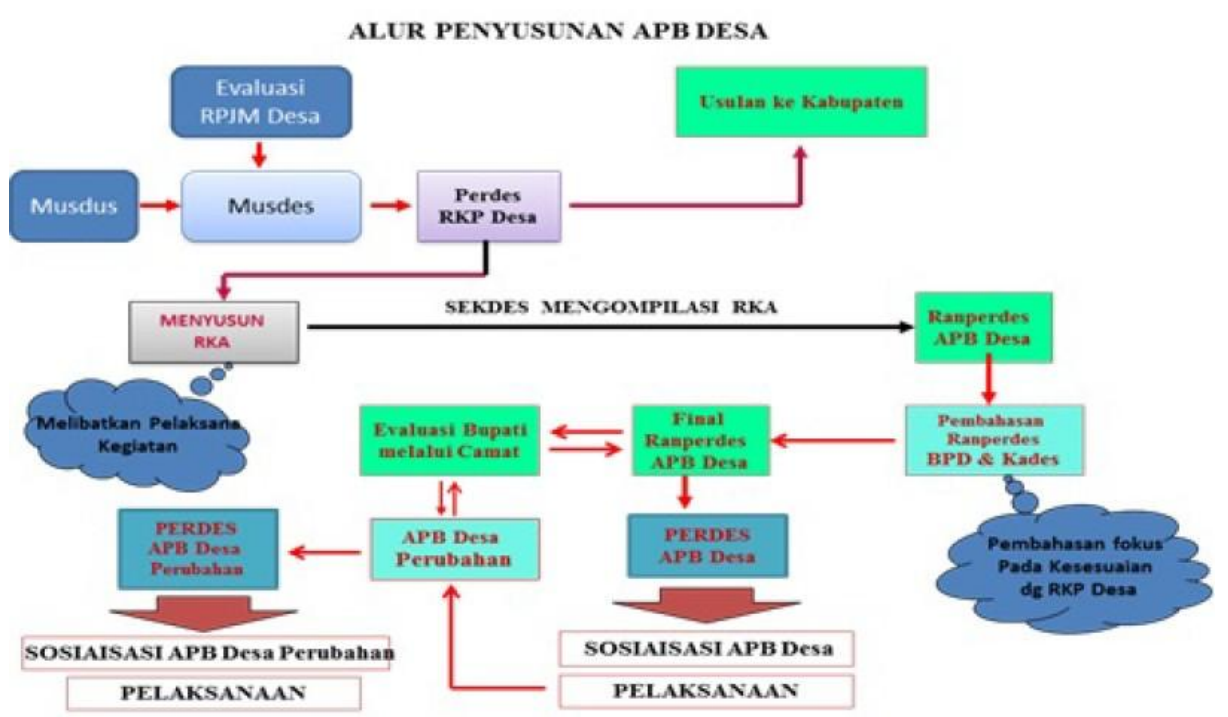

Gambar 1. Alur Penyusunan APBDes

Proses penyunan APBDes ini pada akhirnya setelah menjadi kebijakan APBDes dalam bentuk Peraturan Desa (Perdes) maka harus diinformasikan kepada rakyat di desa tersebut dan disampikan kepada Pemerintah Daerah Kabupaten/Kota sebagai laporan. Dokumen ini penting untuk diketahui oleh berbagai pihak terkait agar terjamin transparansi dan akuntabilitas dalam penyelenggaraan Pemerintahan Desa. 
Dalam hal pengelolaan keuangan desa maka UU No. 06 Tahun 2014 tentang Desa menjadi dasar dalam pelaksanaan kewenangan desa. Alur yang telah ditetapkan dalam pasal UU tersebut harus dilaksanakan. Secara ideal beberapa pasal dalam UU tersebut menjelaskan setiap proses pengelolaan keuangan desa. Proses pengelolaan keuangan desa dilakukan melalui beberapa tahapan. Berikut dapat dilihat gambar alur pengelolaan dana desa:

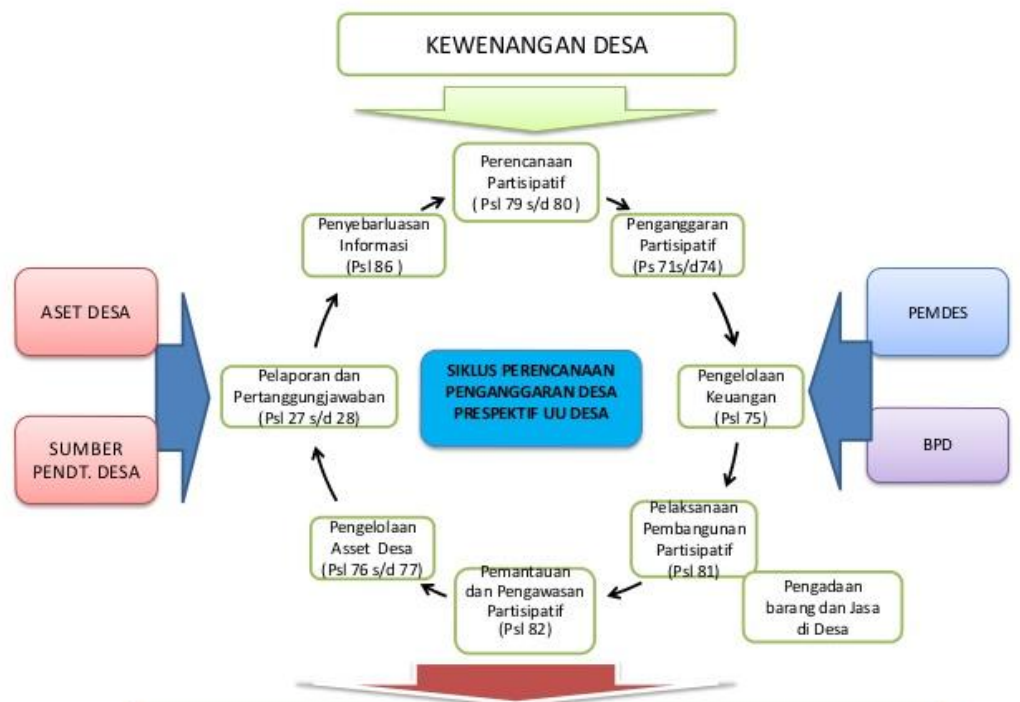

KESEIAHTERAAN DAN KEADILAN SOSIAL MASYARAKAT DESA

Gambar 2. Siklus Alur Penganggaran Desa Berdasarkan UU No. 06/2014

Proses perencanaan penganggaran desa juga harus diketahui oleh pemangku kepentingan agar diketahui sejak awal apabila ada masukan, korekasi, usulan sehingga APBDes sesuai dengan permasaalahan dan kebutuhan warga desa tersebut. Untuk itu jelas adanya alur informasi yang cepat dan mudah menjadi penting. Oleh karenanya aparat pemerintah desa perlu memiliki pengetahuan dan pemahaman serta kemampuan dalam e-government. Penambahan kemampuan pada bidang tersebut penting dilakukan oleh Pemerintan Desa dan pihak terkait.

Program pengabdian kepada masyarakat yang dilakukan oleh tim dosen Ilmu Pemerintahan Universitas Komputer Indonesia dan Universitas Islam 45 dengan obyek sasaran aparat pemerintah desa di Kecamatan Ciampel berbentuk pelatihan e-goverment. Dari desain pelatihan yang diberikan mulai aspek kebijakan e-government, Teknik Presentasi (Power Point) dan Public Speaking dan Pembuatan Aplikasi e-Government. disampaikan dalam tatap muka di kelas dan studi kasus serta praktek dalam aplikasi yang sederhana dengan panduan dari fasilitator.

Berdasarkan hasil evaluasi dan menganalisis dari hasil pelatihan e-government yang telah dilakuka, aparat pemerintahan desa se Kecamatan Ciampel Kabupaten Karawang, nampak selama mengikuti pelatihan mereka sangat antusias, hal tersebut nampak dari sambutan dan berbagai pertanyaan yang disampaikan kepada fasilitator. Kondisi demikian menjadikan hangat dan hidupnya selama berlangsungnya pelatihan. Dari sejumlah pertanyaan yang kemudian dijawab oleh fasilitator, para peserta merasa lebih paham dan mampu dalam mengaplikasikan materi dalam praktek di komputer yang tersedia di tempat pelatihan. 


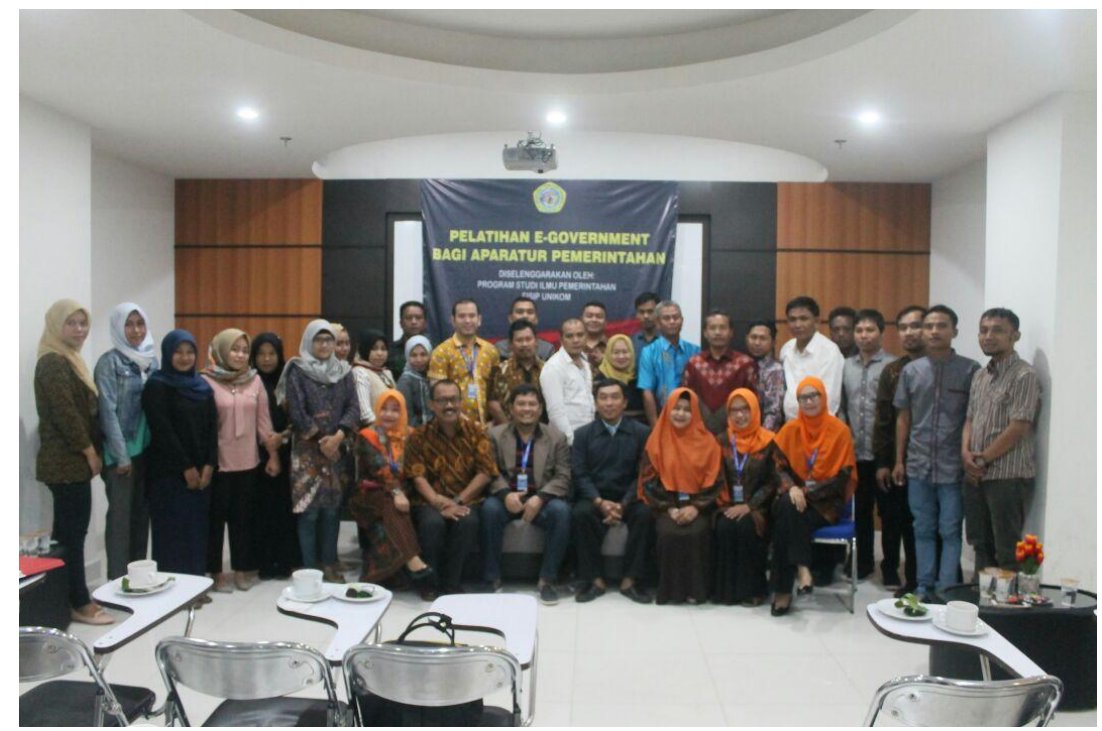

Gambar 3. Poto Bersama Fasilitator dan Peserta Pelatihan

Proses pelatihan dibimbing satu-persatu saat praktek di hadapan computer. Rasa ingin tahu dan tekad ingin bisa dari peserta sangat nampak. Hal ini terutama pada penggunaan e-mail, media sosial dan mencoba membuat blog yang bisa dioptimalkan bagi pelaksanaan pekerjaan mereka di desa. Terkait dengan output dari pelatihan yang dilakukan dapat diketahui dengan dirintisnya web sederhana dan Blog desa dari peserta pelatihan.

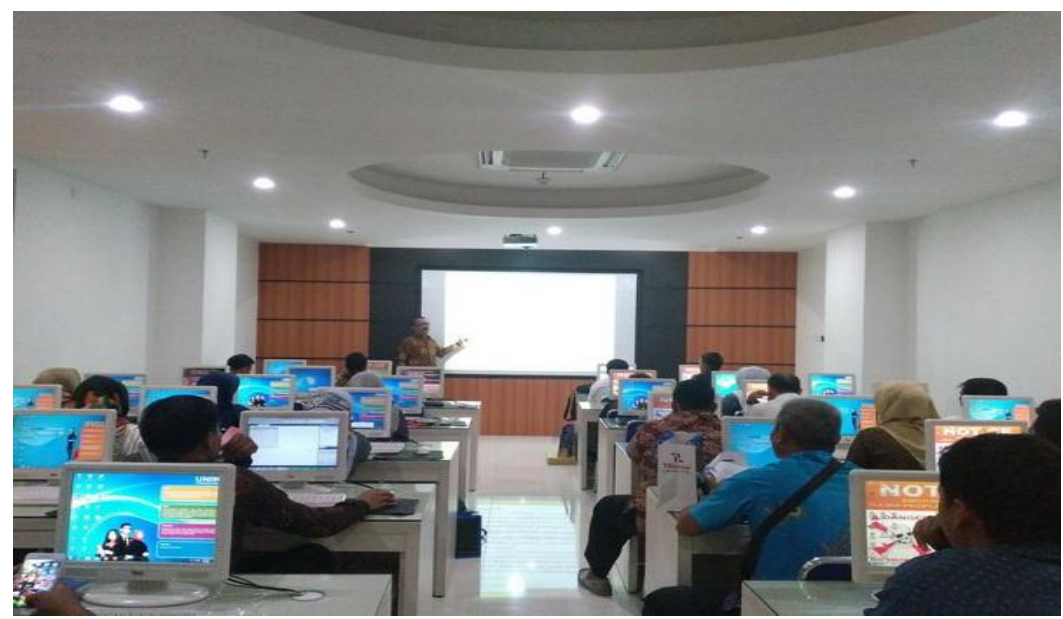

Gambar 4. Pelatihan ICT Bagi Aparat Kecamatan Ciampel Kab. Karawang

Salah satu desa di Kecamatan Ciampel Kabupaten Karawang yang telah mencoba menggunakan teknologi ICT dalam mengoptimalkan penyelenggaraan pemerintahan desa adalah desa Mulyasari. Beberpa informasi yang ada didalamnya yaitu menyangkut kegiatan PNPM Perdesaan, Berbagai kegiatan dan aktivitas perekonomian masyarakat desa, informasi pemerintahan, pembangunan dan lain-lain. Berikut salah satu gambar terkait dengan penggunaan ICT di desa Mulyasari. 


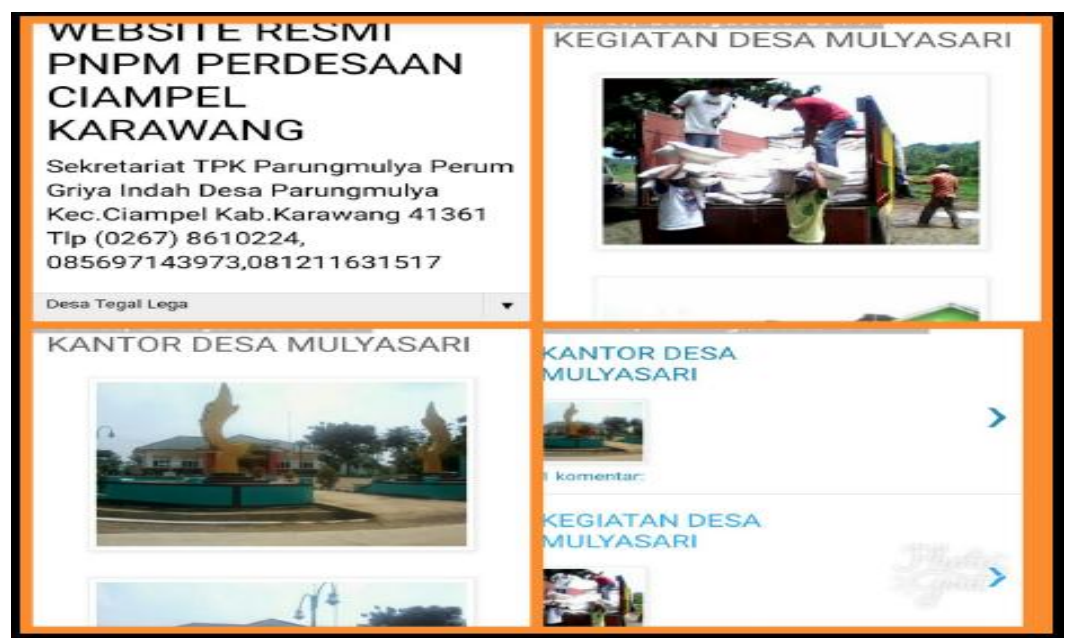

Gambar 5. ICT di Desa Mulyasari Kecamatan Ciampel

Berikutnya dapat dilihat hasil penerapan e-government di desa Kutamekar Kecamatan Ciampel Kabupaten Karawang. Bila kita perhatikan nampak bahwa keberadaan e-government sudah diterapkan dan bermanfaat bagi peny elenggaraan pemerintahan desa.

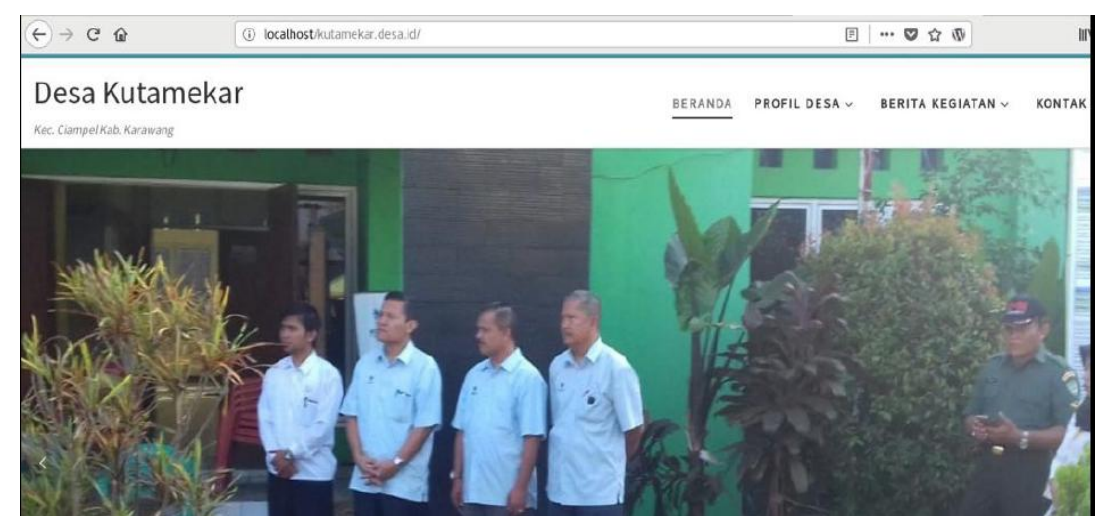

Gambar 6. Web Sederhana di Desa Kutamekar

Dibuatnya website sederhana di desa Kutamekar cukup memudahkan bagi siapapun yang ingin mengetahui lebih jauh. Di dalam web tersebut disajikan beberapa pilihan menu sederhana yang dapat diklik dan tilihat informasi penting, misalnya menyangkut profil desa, perangkat desa dan keuangan desa.

Keberhasilan ini seperti halnya yang dirasakan oleh Kabupaten Sragen dalam pemanfaatan e government. Hartono dkk (2010) menjelaskan bahwa Aplikasi Electronic Government untuk pemberdayaan pemerintahan dan potensi desa berbasis web di Kabupaten Sragen yang terbangun merupakan salah satu media yang dapat diakses setiap saat secara on line oleh 208 desa/kelurahan memungkinkan penyediaan data yang selalu mutakhir. Kondisi seperti itu dalam masa ke depan diharapkan dapat berkembang juga di Kabupaten Karawang. Contoh lain dapat dilihat di hasil penelitian pengabdian kepada masyarakat dari Praditya (2014) bahwa e-government di desa, sebagian besar masih di tahap informasi, dan sebagian kecil berada di tahap interaksi. Pemanfaatan TIK di Desa Panjalu digunakan untuk menyebarluaskan atau diseminasi informasi mengenai kegiatan-kegiatan pembangunan. Pada beberapa gambar berikut menunjukkan pemanfaatan $e$ government di desa-desa pada wilayah Kecamatan Ciampel yang telah diberikan pelatihan melalui KKN Mahasiswa dan P2M pelatihan e government. 


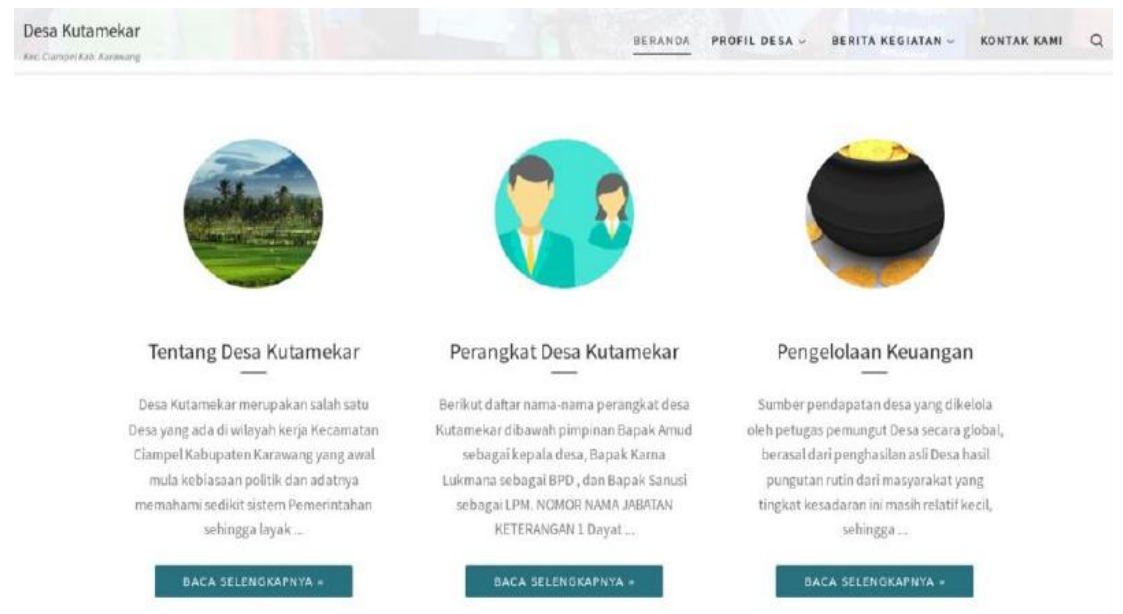

Gambar 7. Daftar Menu Web Sederhana di Desa Kutamekar

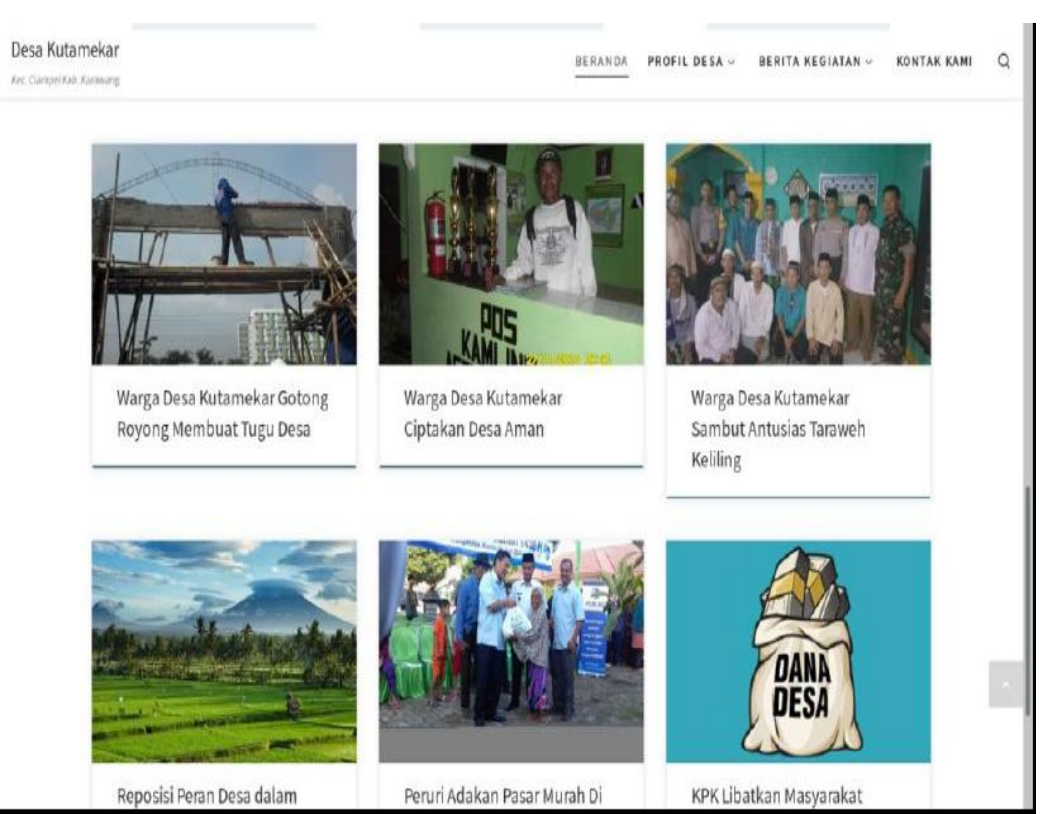

Gambar 5. Informasi Kegiatan Masyarakat dalam Web Sederhana di Desa Kutamekar

Dalam aplikasinya apa yang sudah dilatihkan kepada peserta pelatihan e-government dapat bermanfaat bagi aktivitas pemerintahan dan masyarakat di desa peserta pelatihan. Hal ini cukup menggembirakan dan dapat ditindaklanjuti dalam pendampingan dan pembinaan agar berkelanjutan. Tim fasilitator, lembaga perguruan tinggi, mahasiswa, pemerintah desa dan masyarakat perlu menjalin kerjasama untuk pemanfaatan e-government selanjutnya. Dengan demikian dapat dijamin keberlanjutan e-government di pemerintahan desa se Kecamatan Ciampel Kabupaten Karawang.

\section{KESIMPULAN}

Beberapa hal yang dapat disimpulkan dari kegiatan pelatihan e-government bagi aparat pemerintah desa di Kecamatan Ciampel Kabupaten Karawang adalah sebagai berikut:

1. Pelatihan e-government in campus nampaknya membuat peserta sangat antusias dalam mendapatkan materi pelatihan. Mereka merasa ditinggikan dan terhormat dengan diberi kesempatan datang ke kampus. 
2. Materi pelatihan e-government yang diberikan dapat diterima dengan baik oleh peserta dan mereka mampu mengaplikasikannya secara sederhana dalam bentuk web atau blog yang dipergunakan bagi kepentingan pekerjaan mereka di Pemerintah Desa.

3. Perlu dilakukan pembinaan dan pendampingan kepada peserta pelatihan untuk menjamin keberlangsungan dan keberlanjutan dari hasil pelatihan tersebut. Dengan demikian kebermanfaatan pelatihan e-government dapat terwujud bagi optimalisasi pelayanan kepada masyarakat.

4. Perlu ditindaklanjuti kerjasama dengan Pemerintah Daerah untuk optimalisasi pelatihan egovernment di wilayah lain supaya lebih optimal dan tepat sasaran.

5. Program kegiatan dan pelatihan yang serupa perlu terus dilakukan secara berkelanjutan kepada obyek sasaran di desa-desa di wilayah lain oleh perguruan tinggi yang memiliki program studi terkait dengan e-government.

\section{UCAPAN TERIMAKASIH}

Terimakasih yang sedalam-dalamnya kami ucapkan kepada beberapa pihak yang telah mendorong, mendukung dan membantu terselenggaranya program pengabdian kepada masyarakat

- Pelatihan E Government Bagi Aparat Pemerintah Desa Di Kecamatan Ciampel Kabupaten Karawang. Beberapa pihak tersebut yaitu:

1. Direktur LPPM Universitas Komputer Indonesia;

2. Direktur Sekolah Pascasarjana Universitas Islam 45;

3. Dekan FISIP Universitas Komputer Indonesia;

4. Ketua Program Studi Ilmu Pemerintahan Universitas Komputer Indonesia;

5. Ketua Program Studi Magister Ilmu Pemerintahan Sekolah Pascasarjana Universitas Islam 45;

6. Camat dan Sekretaris Kecamatan Ciampel Kabupaten Karawang;

7. Para Kepala Desa Di Lingkungan Kecamatan Ciampel Kabupaten Karawang;

8. Tim Fasilitator dari Program Studi Ilmu Pemerintahan Universitas Komputer Indonesia dan Program Studi Magister Ilmu Pemerintahan Sekolah Pascasarjana Universitas Islam 45.

\section{DAFTAR PUSTAKA}

Hartono, dkk. 2010. E-Government Pemberdayaan Pemerintahan dan Potensi Desa Berbasis Web. Jurnal Teknologi Informasi.(6:1). Pascasarjana Teknik Informatika Universitas Dian Nuswantoro. Semarang

Hartoyo, Nunik Maharani dan Ika Merdekawati 2016. Upaya Membangun Sistem Informasi Desa, Jurnal Komunikasi Ikatan Sarjana Komunikasi.

Praditya, Didit. 2014. Pemanfaatan Teknologi Informasi dan Komunikasi (TIK) di Tingkat Pemerintahan Desa. Jurnal Penelitian Komunikasi. (17:2). Balai Pengkajian dan Pengembangan Komunikasi dan Informatika (BPPKI). Bandung

Setria, Eddy. 2009, https://www.bappenas.go.id/id/data-dan-informasi-utama/makalah/artikelmajalah-perencanaan/edisi-30-tahun-2003/electronic-government---oleh-eddy-satriya/, diakses 01 Maret 2018, jam 22.04. WIB.

Undang-Undang Nomor 6 Tahun 2014 tentang Desa.

Undang-Undang Nomor 11 Tahun 2008 tentang Informasi dan Transaksi Elektronik.

Instruksi Presiden Republik Indonesia No. 3 Tahun 2003 tentang Kebijakan dan Strategi Nasional Pengembangan E-Government. 